慶應義塾大学学術情報リポジトリ

Keio Associated Repository of Academic resouces

\begin{tabular}{|c|l|}
\hline Title & $\begin{array}{l}\text { Xanthine oxidase-derived oxygen radicals play significant roles in the development of chronic } \\
\text { pancreatitis in WBN/Kob rats. }\end{array}$ \\
\hline Sub Title & $\begin{array}{l}\text { 自然発症慢性膵炎モデルラット(WBN/Kobラット)の膵組織障害におけるxanithine } \\
\text { oxidaseよより産生される活性酸素の関与 }\end{array}$ \\
\hline Author & 是木, 茂幸(Zeki, Shigeyuki) \\
\hline Publisher & 慶應医学会 \\
\hline Publication year & 2003 \\
\hline Jtitle & 慶應医学 (Journal of the Keio Medical Society). Vol.80, No.4 (2003. 12),p.22- \\
\hline JaLC DOI & \\
\hline Abstract & \\
\hline Notes & 号外 \\
\hline Genre & Journal Article \\
\hline URL & https://koara.lib.keio.ac.jp/xoonips/modules/xoonips/detail.php?koara_id=AN00069296-2003120 \\
& 2-0022 \\
\hline
\end{tabular}

慶應義塾大学学術情報リポジトリ(KOARA)に掲載されているコンテンツの著作権は、それぞれの著作者、学会または出版社/発行者に帰属し、その権利は著作権法によって 保護されています。引用にあたっては、著作権法を遵守してご利用ください。

The copyrights of content available on the KeiO Associated Repository of Academic resources (KOARA) belong to the respective authors, academic societies, or publishers/issuers, and these rights are protected by the Japanese Copyright Act. When quoting the content, please follow the Japanese copyright act. 


\title{
Xanthine oxidase-derived oxygen radicals play significant roles in the development of chronic pancreatitis in WBN/Kob rats.
}

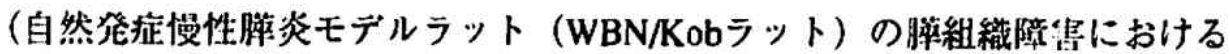 \\ xanthine oxidaseにより産生される活性酸素の関与)
}

\section{是木茂幸}

\section{内谷の要旨}

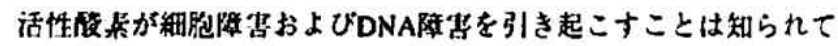

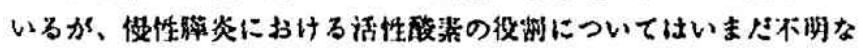
点が多い。今回、者者は自然焦症㨧珄㮦炎モデルラットである WBN/Kobラットを用いて仵住愺炎においてxanthine oxidase (XOD)

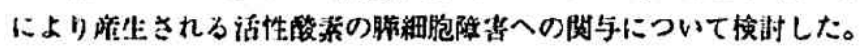

WBN/Kobラットにコントロールの期枓あるいはXOD活性を抑制す

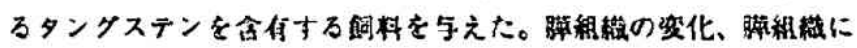

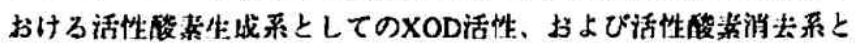
$\iota \tau の$ glutathione (GSH) 量、superoxide dismutase (SOD) 活性を激

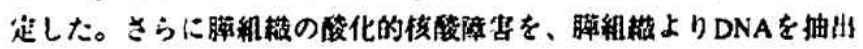
し8-hydroxy-denxyguanosine (8-OH-dG) / /Gを测定することにより険

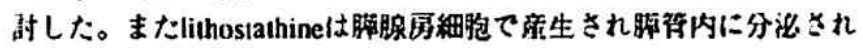

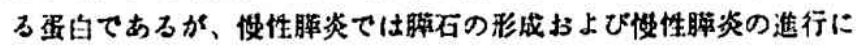

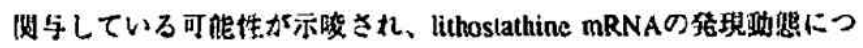
いても抁淂を行った。

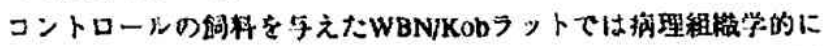

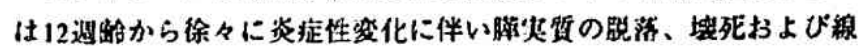

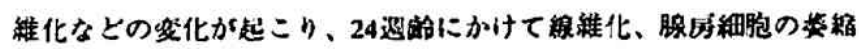
が著明となった。XOD活性は12造踰をビークに有意に上开し、以後

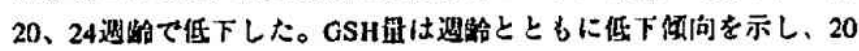

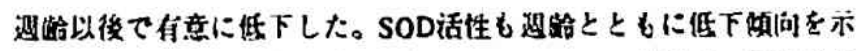

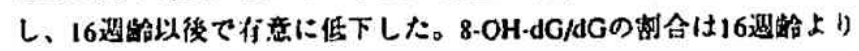

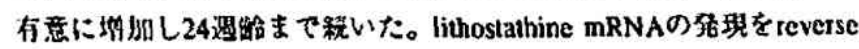
transcription-polymerase chain reaction (RT.PCR) 法で快定昷的に榙讨

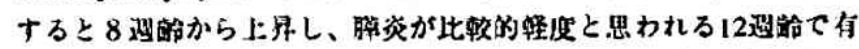

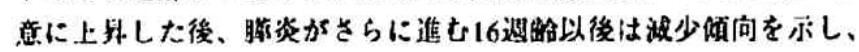

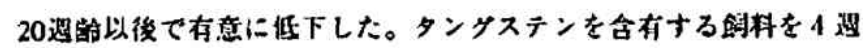

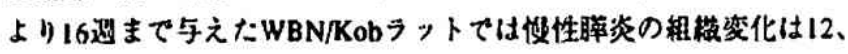
16速路で有意に抑制された。またXOD活性は 8-16迕路で、8-OH一

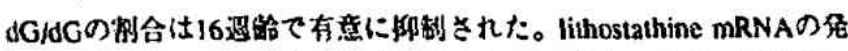

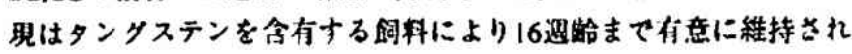
た。

以上の鈢果から、WBN/Kobラットの睡組颢においてXODに上り産

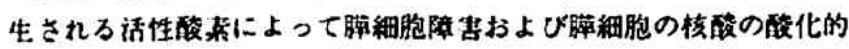

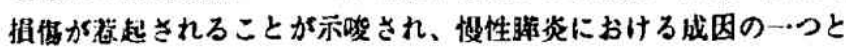
名えられた。

\section{論文铬查の要旨}

近年、多くの脑热の帒症に酸化ストレスの临与が報告されている

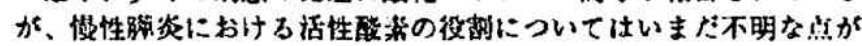

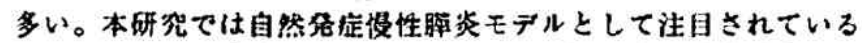
WBN/Kobフットを用いて、xanihine oxidase (XOD) により䃏生され

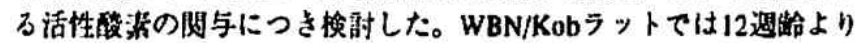

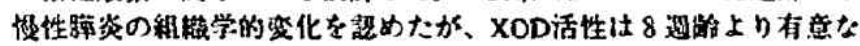

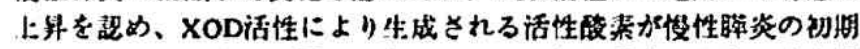

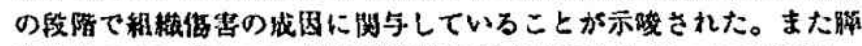

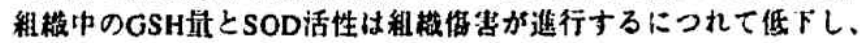

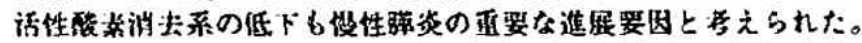

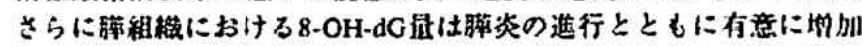

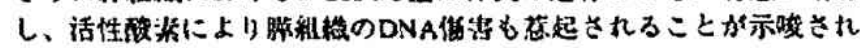

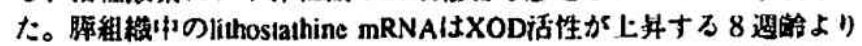

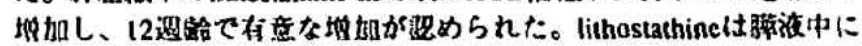

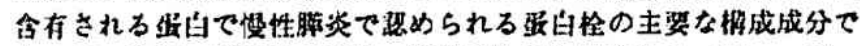

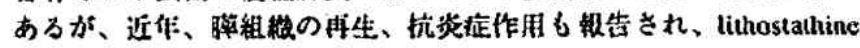

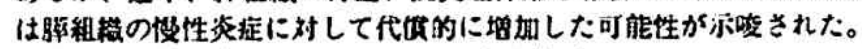

查ではまず、WBN/Kobラット血济中のamylase、proly!

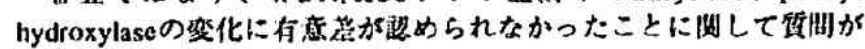

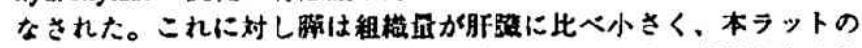

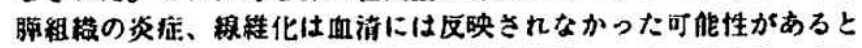
回答されたが、血清中でモニターできる他のマーカーにつき、さら

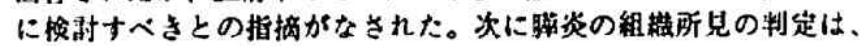

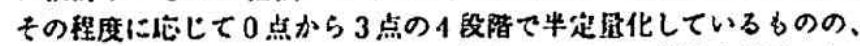

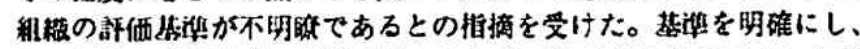
その判定に淤理学者の竞見を取り入れるへさであるとのコメントが なミれた。またDNAの俊化的担侮についてXOD活性が8-16选答で

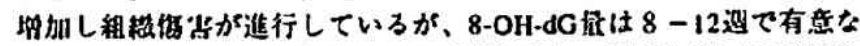

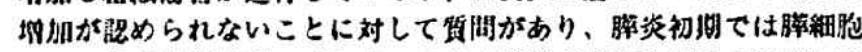
のDNA修復譏挴が儌いており、かなり愺炎が速行してか58-OH-dG 调が增加してきた可能珄があると回答された。さらにXOD活性の測

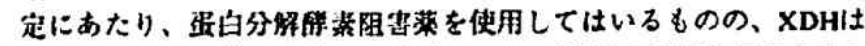
XODに此較的容易に变化しやすく、XODの活性の增波を併価するの にmRNAレベルで測定することが助畐された。

以上、本研究は今後榆时されるべき課题を残してはいるものの、 侵性椫炎の発生・進展逍程において、XOD活性に上り应生される活

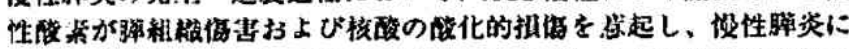
おける成因の一つとして而姴であることを示した点で消化器苪学上: 住意接な研究と洋価された。

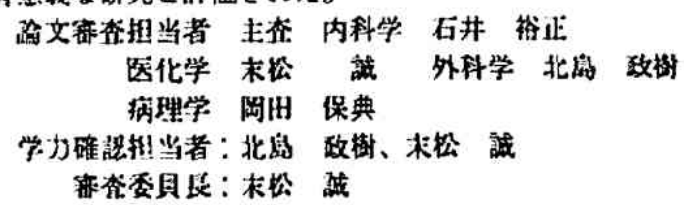

武沜日：平成15年10月10日 